\title{
Physicochemical, nutritional, and antioxidant characteristics of the fruit of Ehretia tinifolia
}

\section{Características fisicoquímicas, nutricias y antioxidantes del fruto de Ehretia tinifolia}

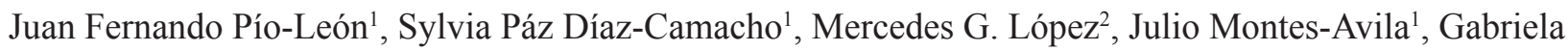
López-Angulo ${ }^{1}$ and Francisco Delgado-Vargas ${ }^{1 凶}$

${ }^{1}$ Facultad de Ciencias Químico Biológicas, Universidad Autónoma de Sinaloa, Cd. Universitaria, 80010 Culiacán, Sinaloa, México.

${ }^{2}$ Unidad de Biotecnología e Ingeniería Genética de Plantas, Centro de Investigación y de Estudios Avanzados, Instituto Politécnico Nacional, Km. 9.6 Libramiento Norte, Carretera Irapuato-León, 36500 Irapuato, Guanajuato, México.

$\bigotimes$ fdelgado@uas.uasnet.mx

\begin{abstract}
Physicochemical characteristics of Ehretia tinifolia L. fruit are presented for the first time. The fruit of this plant is a small drupe of $8 \mathrm{~mm}$ diameter and weighs $0.2 \mathrm{~g}$. Its pulp is slightly acidic $(\mathrm{pH} 5.8)$ with a high ratio of soluble solids $\left(11^{\circ}\right.$ Brix) to acidity $(0.1 \%)$. The antioxidant activity of E. tinifolia fruits (DPPH, $303.8 \mathrm{mg} \mathrm{EVC} / 100 \mathrm{~g}$ f.w.; ABTS, $84.1 \mathrm{mg}$ EVC/100 g f.w.; DPPH, ABTS and EVC mean 1,1-diphenyl-2-picrylhydrazyl, 2,2'-azino-bis(3ethylbenzothiazolin-6-sulfonate) diammonium salt, and equivalents of vitamin $\mathrm{C}$, respectively) was similar or higher than reported for several tropical fruits (e.g. orange, guava, and prickly pear). Ehretia tinifolia fruit has a high content of ash (12.6 mg/100 g d.w.). The edible portion is an important source of selenium $(0.1 \mathrm{mg} / 100 \mathrm{~g} \mathrm{~d} . \mathrm{w}$.) and total fatty acids were $834.8 \mathrm{mg} / 100 \mathrm{~g}$ d.w.; the main fatty acids were palmitic $(27.6 \%)$, linoleic $(26.4 \%)$, linolenic $(18.1 \%)$, and oleic (17.6\%). The content of fatty acids of seeds was $5137.5 \mathrm{mg} / 100 \mathrm{~g}$ d.w., with linoleic (54.3\%), oleic (22.9\%), and palmitic $(12.7 \%)$ as main components.
\end{abstract}

Key words: nutriment, nutraceutic, phenolics, fatty acids, tannins, phytic acid, proximate analysis.

Resumen. Se presentan por vez primera características fisicoquímicas del fruto de Ehretia tinifolia L. Este fruto es una drupa pequeña de $8 \mathrm{~mm}$ de diámetro y $0.2 \mathrm{~g}$, su pulpa es ligeramente ácida ( $\mathrm{pH}$ 5.8) y la relación de sólidos solubles ( $11^{\circ}$ Brix) a acidez (0.1\%) es alta. La actividad antioxidante de los frutos de E. tinifolia (DPPH, $303.8 \mathrm{mg} \mathrm{EVC/100} \mathrm{g}$ p.f.; ABTS, $84.1 \mathrm{mg}$ EVC/100 g p.f.; EVC significa equivalentes de vitamina C) fue similar o mayor que lo registrado para varios frutos tropicales (e.g. naranja, guayaba o tuna). El fruto presenta un alto contenido de cenizas (12.6 mg/100 g p.s.). La porción comestible es una fuente importante de selenio $(0.1 \mathrm{mg} / 100 \mathrm{~g}$ p.s. $)$ y el total de ácidos grasos fue de $834.8 \mathrm{mg} / 100 \mathrm{~g}$ p.s.; los principales ácidos grasos fueron palmítico (27.6\%), linoleico (26.4\%), linolénico (18.1\%) y oléico (17.6\%). El contenido de ácidos grasos de las semillas fue $5137.5 \mathrm{mg} / 100 \mathrm{~g}$ p.s.; siendo los principales componentes el linoleico (54.3\%), oleico (22.9\%) y palmítico $(12.7 \%)$.

Palabras clave: nutrimento, nutracéutico, fenólicos, ácidos grasos, taninos, ácido fítico, análisis proximal.

\section{Introduction}

Ehretia tinifolia L. (Boraginaceae) is an evergreeen tree, up to $25 \mathrm{~m}$ high. The common name of this plant in Sinaloa, México is pingüica, which probably comes from a modification of pingüico, the name used in Nayarit and Coahuila. It is found in Central America, southeast Mexico, Cuba, and Honduras. This plant is native from the South of Mexico, but is widely distributed in other states (e.g. Michoacán, Nayarit, San Luis Potosí, Sinaloa, Tamaulipas, and Veracruz) (Martínez, 1979; Miller, 1989; BenítezBadillo et al., 2004; Monrroy-Ortíz and Monrroy, 2006).

Recibido: 12 marzo 2011; aceptado: 27 mayo 2011
E. tinifolia is part of the tropical rainforest and of the subdeciduous and deciduous forest, found from 0 to $1400 \mathrm{~m}$ asl, and is commonly used in gardens and public parks for its ornamental characteristics (Miller, 1989; Monrroy-Ortíz and Monrroy, 2006). The tree has been also used as a source of wood and medicine, whereas fruits as food and feed (Martínez, 1979; Lara-López and González-Romero, 2002; Benítez-Badillo et al., 2004; Capistran-Barradas et al., 2006; Monrroy-Ortíz and Monrroy, 2006). Leaf preparations are used to treat nervous disorders and kidney inflammation; and those of bark for respiratory illnesses and wound healing (Benítez-Badillo et al., 2004; Monrroy-Ortíz and Monrroy, 2006; Argueta and Mata, 2009a, 2009b).

Ehretia tinifolia fruits are small globoid drupes of up to $8 \mathrm{~mm}$ diameter; their color changes from green 
to yellow (stage of physiologic ripening) and finally to purple-red by maturation (Miller, 1989; Monrroy-Ortíz and Monrroy, 2006). The Ehretia genera are classified in Ehretia I, II, and III based on fruit morphology; E. tinifolia belongs to type II, drupaceous fruits with the endocarp divided in halves (Gottschling and Hilger, 2004). These fruits are sweet and have been used as food in several regions of Mexico (Martínez, 1979; BenítezBadillo et al., 2004; Monrroy-Ortíz and Monrroy, 2006); however, E. tinifolia fruits have been scarcely studied for their nutritional characteristics.

Throughout the world more than 195000 flowering plants species produce edible parts with potential as food but less than $0.1 \%$ are used; corn, rice, and wheat are the main source of energy in the human diet, and remarkably, a large number of emerging diseases are associated with a less diverse diet (Cordain, 1999). Additionally, epidemiological data have shown a positive correlation between a high consumption of fruits and vegetables and improved health (for example, reduced risk of being affected by chronic diseases and increased longevity) (Delgado-Vargas and Paredes-López, 2002; Kaliora and Dedoussis, 2007). Fruits and vegetables are good sources of vitamins, minerals, fiber, and antioxidant compounds, and some of them of essential fatty acids (Muller and Tobin, 1986; Kaur and Kapoor, 2001); they also have non-nutritional phytochemicals such as pigments, phenolics, and phytic acid (better known as an antinutritional compound) which contribute the preservation and/or recovery of human health. As a matter of fact, several fruits and vegetables have been considered as functional foods (Martínez-Valverde et al., 2000; Kaur and Kapoor, 2001; Delgado-Vargas and Paredes-López, 2002; Shamsuddin, 2002; Lule and Xia, 2005).

Pingüica trees and their fruits are underused. In this research, physicochemical, nutritional and antioxidant characteristics of these fruits are presented, with the aim of promoting the rational use of this plant.

\section{Materials and methods}

Sample collection and storage. Ehretia tinifolia fruits were collected in the yellow stage (physiologic maturity) from Culiacán, Sinaloa, Mexico. Dr. Rito Vega-Aviña helped us with plant material identification and a voucher specimen (var 3125) was deposited at the Faculty of Agronomy of the Autonomous University of Sinaloa. Fresh fruit analysis was carried out the same day of collection. Remaining fruits were freeze-dried (VirTis 25EL, VirTis Co., USA) and milled, pulp was separated from seeds using a no. 40 mesh screen, and samples were stored $\left(-30^{\circ} \mathrm{C} /\right.$ darkness $)$.
Physicochemical analyses of fresh fruit samples. Color parameters $\left(\mathrm{L}^{*} ; \mathrm{a}^{*} ; \mathrm{b}^{*}\right)$ were determined with a reflectance colorimeter CR-310 (MINOLTA Co., Japan). The size of the fruit was determined with a dial caliper (GENERAL, Switzerland) at two equatorial points, equally spaced at $90^{\circ}$, and one axial point. Weight was determined using an analytical balance. Fruits were randomly selected and the results were registered as the average of 25 measurements.

Chemical analyses were carried out by standard methods (AOAC, 1990): soluble solids with an Abbe refractometer (Milton Roy Co., USA) and represented as ${ }^{\circ} \mathrm{Brix}$; $\mathrm{pH}$ with a digital $\mathrm{pH}$ meter (Orions, USA); total acidity, and moisture. All analyses were carried out in quintuplicate on ripe fruit.

Vitamin C was extracted using two solvent systems: cold water or citric acid solution (0.1 M, EDTA $0.05 \%$ w/v) (Zapata and Dufour, 1992). Fresh fruit sample (10 g) was extracted with the chosen solvent $(20 \mathrm{~mL})$, sample was homogenized by sonication ( $5 \mathrm{~min}$ ), filtered through cheesecloth, filtrate was recovered and residue was re-extracted, and filtrates were mixed. Filtrate was cleaned using a $0.45 \mu \mathrm{m}$ filter and passed through a Sep-Pak C18 cartridge, previously equilibrated with acetonitrile and water. The sample was analyzed by HPLC, Agilent 1100 HPLC with DAD detection (Agilent Technologies, Palo Alto California, USA), using a SHEROCLONE ODS column $(250 \times 4.6 \mathrm{~mm} \times 5 \mu \mathrm{m})$ (Phenomenex; Torrance, $\mathrm{CA}$ ); elution was carried out with a $\mathrm{KH}_{2} \mathrm{PO}_{4}$ solution (25 $\mathrm{mM}$ ), and detection at $254 \mathrm{~nm}$. Quantification was done by using a calibration curve of ascorbic acid.

Total phenolics and antioxidant activity. The analyses were carried out with two types of extracts, using methanol or ethanol. Fresh fruits (10-15 g) were milled in a mortar $(2 \mathrm{~min})$. Homogenized sample was mixed with solvent $(100 \mathrm{~mL})$ in a $250 \mathrm{~mL}$ flask, sonicated $(10$ min), and passed through Whatman 1 filter paper; filtrate was recovered and residue was re-extracted, filtrates were mixed and used for total phenolics and antioxidant activity determinations.

Total phenolics were determined as described previously (Wrolstad, 2001). Briefly, sample obtained with methanol or ethanol $(20 \mu \mathrm{L})$ was mixed with water $(1.58$ $\mathrm{mL}$ ) and Folin-Ciocalteu reagent $(0.1 \mathrm{~mL})$, mixed $(5 \mathrm{~min})$, and added with a saturated solution of sodium carbonate $(0.3 \mathrm{~mL})$. The mixture was incubated $\left(40^{\circ} \mathrm{C} / 30 \mathrm{~min}\right)$ and measured at $765 \mathrm{~nm}$. Phenolics were calculated using a calibration curve of gallic acid and results expressed as $\mathrm{mg}$ equivalents of gallic acid per $100 \mathrm{~g}$ of fresh fruit.

The antioxidant activity using DPPH was carried as follows: Sample $(0.2 \mathrm{~mL})$ was mixed with a DPPH solution $\left(150 \mu \mathrm{M}\right.$ in methanol), incubated $\left(30 \mathrm{~min} / 25^{\circ} \mathrm{C} /\right.$ 
darkness), and measured at $517 \mathrm{~nm}$. Antioxidant activity was calculated as

$$
\% \text { decoloration }=\left[\frac{\mathrm{A}_{\mathrm{C}}-\mathrm{A}_{\mathrm{s}}}{\mathrm{A}_{\mathrm{C}}}\right] * 100,
$$

where: $A_{c}=$ absorbance of control; $A_{s}=$ absorbance of sample. Standard curves were prepared using vitamin $\mathrm{C}$ and Trolox, and results were expressed as equivalents of vitamin $\mathrm{C}$ (EVC) and of Trolox (TE), both per $100 \mathrm{~g}$ of fresh fruit.

The antioxidant activity using ABTS was determined with the methodology reported by Liu et al. (2009) with slight modifications. Briefly, ABTS radical was prepared by mixing $7 \mathrm{mM}$ ABTS with $2.5 \mathrm{mM}$ potassium persulfate; the mixture was incubated ( $16 \mathrm{~h} /$ darkness $)$, and diluted with methanol to get an absorbance of $0.7 \pm 0.05$ at $734 \mathrm{~nm}$. Sample $(0.05 \mathrm{~mL})$ and the ABTS radical solution $(1.95 \mathrm{~mL})$ were mixed and was incubated $\left(37^{\circ} \mathrm{C} / 10 \mathrm{~min}\right)$. Antioxidant activity as decoloring capacity was calculated with the above formula, and results were expressed as EVC and TE per $100 \mathrm{~g}$ of fresh fruit.

Analyses of dried fruit samples. The proximate composition (moisture; crude protein, Micro Kjeldahl, $\mathrm{N} \times 6.25$; fat; crude fiber, and ash) was estimated by standard methods (AOAC, 1990). Energy value was calculated using the conversion factors of Merrill and Watt (1973) and the carbohydrate content determined by difference.

Samples for mineral analyses were prepared as described by Alcántar-González and Sandoval-Villa (1999). Mineral content was evaluated with an atomic absorption spectrometer SpectrAA-220 (Varian Inc., Palo Alto, California, USA) as previously reported (Montiel-Herrera et al., 2004; Montiel-Herrera et al., 2005; Pío-León et al., 2009).

Data analyses of the nutritional content were calculated on $100 \mathrm{~g}$ of fresh fruit. Content was considered high $(\geq$ $20 \%)$, good $(10-20 \%)$ or poor $(<10 \%)$ depending on its contribution to the recommended/adequate daily intake of the corresponding nutrient, Code of Federal Regulation (CFR), section 101.54 (FDA, 2009; FNB/FNIC, 2010) and dietary recommendations for Mexico (DRM) (Bourges et al., 2009).

Phytic acid was extracted and measured colorimetrically as described by Latta and Eskin (1980). Analyses were carried out in quintuplicate.

Tannins were determined as described by Price et al. (1978) and expressed as catechin equivalents (g/100 g d.w.). Analyses were carried out in quintuplicate.

Fatty acids were determined as described by Park and Goins (1994) with slight modifications. Sample (50 mg of meal, pulp or seed) was mixed with dichloromethane $(100 \mu \mathrm{L})$ in a $10 \mathrm{~mL}$ screw-capped tube; nonadecanoic acid $(50 \mu \mathrm{L})$ was added as internal standard (C19:0, 10mg/ $\mathrm{mL}$; SUPELCO Inc., Germany), as well as $\mathrm{NaOH} 0.1 \mathrm{M}$ in methanol $(1 \mathrm{~mL})$. Tubes were evacuated with $\mathrm{N}_{2}(\mathrm{~g})$, closed, heated in a water bath $\left(10 \mathrm{~min} / 90^{\circ} \mathrm{C}\right)$, and cooled to room temperature $\left(25^{\circ} \mathrm{C}\right)$. One $\mathrm{mL}$ of $\mathrm{BF}_{3}(14 \%$ in methanol) was added and air was evacuated with $\mathrm{N}_{2}(\mathrm{~g})$. The tube was closed, heated $\left(90^{\circ} \mathrm{C} / 10 \mathrm{~min}\right)$, and cooled $\left(25^{\circ} \mathrm{C}\right)$. Methyl esters were extracted by water $(1 \mathrm{~mL})$ and hexane $(1 \mathrm{~mL})$ partition; the mixture was vortex mixed $(10$ s) and centrifuged (5000 rpm/3 min); the hexanic phase was recovered and the aqueous phase was washed twice with hexane. Hexane phases were pooled and washed with distilled water, water residues were eliminated by passing throughout an anhydrous sodium sulphate column ( 1 x 5 $\mathrm{cm})$. Hexane was evaporated under $\mathrm{N}_{2}(\mathrm{~g})$ stream and the residue was suspended into $1 \mathrm{~mL}$ of 2,2,4-trimethyl pentane for the GC analysis.

Fatty acid determination was carried out in an HP-6890-Series-II-Plus gas chromatograph coupled with a Mass Selective Detector 5973N (Agilent Technologies, Palo Alto California, USA). Sample was separated in a Quadrex-series-007 column (30 m x $0.25 \mathrm{~mm}$ i.d. x 0.25 $\mu \mathrm{m})$ (Quadrex Corp., Woodbridge, Connecticut, USA). Separation conditions were: injected volume $1 \mu \mathrm{L}$; injector temperature $230^{\circ} \mathrm{C}$; helium as carrier gas $(1 \mathrm{~mL} / \mathrm{min}$, split ration 50:1); detector temperature was $245^{\circ} \mathrm{C}$ in the interface, $230^{\circ} \mathrm{C}$ in the ionization source, and $180^{\circ} \mathrm{C}$ in the quadrupole; column temperature was $100^{\circ} \mathrm{C}, 10^{\circ} \mathrm{C} / \mathrm{min}$ up to $150^{\circ} \mathrm{C}, 3^{\circ} \mathrm{C} / \mathrm{min}$ up to $180^{\circ} \mathrm{C}, 10^{\circ} \mathrm{C} / \mathrm{min}$ up to $240^{\circ} \mathrm{C}$, and $15 \mathrm{~min}$ at $240^{\circ} \mathrm{C}$.

For the fatty acid quantification, fatty acid standards were methylated as described above and solutions of known concentrations were prepared. Samples were injected in order to obtain a response factor (RF) for each fatty acid standard. For those fatty acids present in samples whose standards were not available, a RF of 1 was assigned (Rubinson and Neyer-Hilvert, 1997). RF was calculated as

$$
\mathrm{RF}=\frac{\mathrm{A}_{\mathrm{S}}}{\mathrm{A}_{\mathrm{IS}}},
$$

where, $A_{S}$ and $A_{I S}$ are the area for the standard and for the internal standard, respectively.

Fatty acid concentration was calculated with the formula

$$
C_{X}=\frac{\left(A_{X}\right)\left(R F_{X}\right)}{\left(A_{I S}\right)\left(C_{I S}\right)},
$$

where, $C_{X}, A_{x}$ and $\mathrm{RF}_{\mathrm{X}}$ are the concentration, area, and response factor for the fatty acid, respectively; and $\mathrm{A}_{\mathrm{IS}}$ and 
$\mathrm{C}_{\mathrm{IS}}$ are the corresponding variables for the internal standard. Results are the average of three independent measurements. Statistical analyses. Excel (Microsoft Corp., USA) was used for statistical analysis. Determinations were carried out at least by triplicate and expressed as means $\pm \mathrm{SD}$.

\section{Results}

The yellow stage of E. tinifolia fruits was characterized by negative values for redness $\left(\mathrm{a}^{*}\right)$ and positive values for yellowness $\left(b^{*}\right)$ (Table 1); then fruit color changes to the red-brown characteristic of the over-ripened stage. Pingüica fruits are small and mainly composed of pulp, which is the edible portion; the pulp/seed weight ratio was $\sim 8: 1$. Fruits are rounded and slightly flattened, equatorial size $(8.3 \times 8.7 \mathrm{~mm})$ greater than axial size $(7.4$ $\mathrm{mm}$ ) (Table 1).

Ehretia tinifolia fruits were characterized by a high content of soluble solids, low acidity, and high moisture, whereas vitamin $\mathrm{C}$ was undetected (Table 1).

The main components of pingüica fruit were carbohydrates (65.5\% d.w., calculated by difference), followed by proteins, ash, and crude fiber. On the other hand, considering the anti-nutritional compounds, these fruits were richest in phytic acid (Table 1).

If fresh pingüica fruits are consumed, they could be considered as a high source of Se, providing $22.4 \%$ of the recommended dietary allowance (RDA) $(21.7 \%$ of the DRM), a good source of $\mathrm{Mg}(10 \%$ of the RDA; $10.7 \%$ of the DRM), and a poor source of Fe and $\mathrm{Mn}$, each contributing with $\sim 6.4 \%$ of the RDA and Adequate Intake (AI) (Fe, $4.8 \%$ of the DRM), respectively; and of $\mathrm{Ca}(4.9 \%$ of the AI; same value for the DRM) and $\mathrm{Zn}$ (3.5\% of the RDA; $2.3 \%$ of the DRM) (Table 1 ).

Antioxidant activity and phenolics content of pingüica fruits were higher in the methanolic extract than in the ethanolic extract. Moreover, the DPPH method gave higher antioxidant values than the ABTS method (Table 2).

As expected, the fatty acids were much higher in seeds (5 $137.5 \mathrm{mg} / 100 \mathrm{~g} \mathrm{d.w}$.) than in pulp $(834.8 \mathrm{mg} / 100$ $\mathrm{g}$ d.w.), and the main components in both parts were unsaturated acids (pulp 64.7\%; seed 79.5\%); however, palmitic acid was the highest in pulp (27.6\%). Linolenic acid was undetected in the seeds of E. tinifolia, an essential fatty acid found in pulp (Table 3 ).

\section{Discussion}

Ehretia tinifolia fruits collected at Sinaloa were larger than those of previous reports (5-7 mm) (Miller, 1989; Benítez-Badillo et al., 2004; Monrroy-Ortíz and Monrroy,
Table 1. Physicochemical analyses of the Ehretia tinifolia fruit

\begin{tabular}{|c|c|}
\hline Fresh fruit & \\
\hline \multicolumn{2}{|l|}{ Outer color of ripe fruit ${ }^{a}$} \\
\hline $\mathrm{L}^{*}$ & $47.8 \pm 1.91$ \\
\hline$a^{*}$ & $-4.7 \pm 1.09$ \\
\hline$b^{*}$ & $23.8 \pm 1.84$ \\
\hline \multicolumn{2}{|l|}{ Dimensions $(\mathrm{mm})^{\mathrm{a}}$} \\
\hline Axial & $7.4 \pm 0.42$ \\
\hline Equatorial 1 & $8.7 \pm 0.53$ \\
\hline Equatorial 2 & $8.3 \pm 0.50$ \\
\hline Weight $(\mathrm{g})^{\mathrm{a}}$ & $0.2 \pm 0.05$ \\
\hline Pulp (\%) & $88.7 \pm 0.48$ \\
\hline Seed $(\%)$ & $11.3 \pm 0.48$ \\
\hline $\mathrm{pH}^{\mathrm{b}}$ & $5.8 \pm 0.01$ \\
\hline Total acidity ${ }^{\mathrm{b}, \mathrm{c}}$ & $0.1 \pm 0.01$ \\
\hline Soluble solids $\left({ }^{\circ} \mathrm{Brix}\right)^{\mathrm{b}}$ & 11 \\
\hline Vitamin C (mg/100g) ${ }^{\mathrm{b}}$ & 0.0 \\
\hline \multicolumn{2}{|l|}{ Dried fruit } \\
\hline \multicolumn{2}{|l|}{ Proximate composition $(\%)^{b, d}$} \\
\hline Moisture & $88.7 \pm 0.64$ \\
\hline Protein & $16.5 \pm 0.18$ \\
\hline Lipids & $0.2 \pm 0.03$ \\
\hline Ash & $12.6 \pm 0.04$ \\
\hline Crude fiber & $5.2 \pm 0.11$ \\
\hline Energy $(\mathrm{kJ})$ & 1227 \\
\hline Tannins $(\mathrm{mg} / 100 \mathrm{~g})^{\mathrm{b}}$ & $0.4 \pm 0.03$ \\
\hline Phytic acid (mg/100g) ${ }^{\mathrm{b}}$ & $1580.0 \pm 159.00$ \\
\hline \multicolumn{2}{|l|}{ Minerals $(\mathrm{mg} / 100 \mathrm{~g})^{\mathrm{b}}\left(\mathrm{RDA}^{\mathrm{e}} / \mathrm{AI}^{\mathrm{f}}\right)$} \\
\hline $\mathrm{Ca}(1300 \mathrm{mg})^{\mathrm{f}}$ & $520.0 \pm 60.00$ \\
\hline $\mathrm{Co}(\mathrm{NE})$ & $2.2 \pm 0.41$ \\
\hline $\mathrm{Fe}(18 \mathrm{mg})^{\mathrm{e}}$ & $9.4 \pm 0.42$ \\
\hline $\mathrm{Mg}(420 \mathrm{mg})^{\mathrm{e}}$ & $340.0 \pm 40.00$ \\
\hline $\operatorname{Mn}(2.3 \mathrm{mg})^{\mathrm{f}}$ & $1.2 \pm 0.18$ \\
\hline $\operatorname{Se}(55 \mu \mathrm{g})^{\mathrm{e}}$ & $0.1 \pm 0.01$ \\
\hline $\mathrm{Zn}(11 \mathrm{mg})^{\mathrm{e}}$ & $3.1 \pm 0.23$ \\
\hline
\end{tabular}

${ }^{a}$ The values are the mean \pm SD of 25 measurements.

${ }^{\mathrm{b}}$ The values are the mean $\pm \mathrm{SD}$ of 5 measurements.

${ }^{c}$ Determined as percentage of citric acid.

${ }^{d}$ Values are in dry weight basis (d.w.) with the exemption of moisture. For energy calculation, carbohydrates were determined by difference.

e Recommended dietary allowances.

${ }^{\mathrm{f}}$ Adequate Intakes; NE= Not established, the daily intake value has not been established due to lack of data on adverse effects (FNB/FNIC, 2010).

2006) and were similar to Zizyphus sonorensis fruits, native to Sinaloa (Montiel-Herrera et al., 2005). The sweet flavor of pingüica fruits, previously reported by MonrroyOrtíz and Monrroy (2006), was characterized by a high ratio of soluble solids to acidity (Table 1 ). The $\mathrm{pH}$ values of pingüica fruits were higher than those of citric fruits 
Table 2. Total phenolics and antioxidant activity per $100 \mathrm{~g}$ (f.w.) of the fresh pulp of pingüica fruit (Ehretia tinifolia L.)*

\begin{tabular}{lccccc}
\hline Extract & Total phenolics $(m g)$ & \multicolumn{2}{c}{ DPPH* } & \multicolumn{2}{c}{ ABTS* } \\
& & $\mu M E T$ & $m g E V C$ & $\mu M E T$ & $m g E V C$ \\
\hline Methanolic & $125.45 \pm 2.9$ & $1637.6 \pm 36.0$ & $303.8 \pm 6.9$ & $107.5 \pm 8.0$ & $84.1 \pm 6.3$ \\
Ethanolic & $50.25 \pm 6.85$ & $386.4 \pm 1.2$ & $71.94 \pm 0.2$ & $56.4 \pm 2.0$ & $45.5 \pm 0.3$ \\
\hline
\end{tabular}

* Values are given per $100 \mathrm{~g}$ of fruit on a fresh weight basis (f.w.).

$\mu \mathrm{M} \mathrm{ET}=$ micromole Trolox equivalents.

$\mathrm{mg} \mathrm{EVC}=$ milligrams vitamin $\mathrm{C}$ equivalents.

Table 3. Fatty acid composition of Ehretia tinifolia fruit ${ }^{\mathrm{a}}$

\begin{tabular}{|c|c|c|c|c|}
\hline \multirow[b]{2}{*}{ Fatty acid } & \multicolumn{2}{|c|}{ Pulp } & \multicolumn{2}{|c|}{ Seed } \\
\hline & $m g / 100 g^{b}$ & $\% c$ & $m g / 100 g^{b}$ & $\%$ \\
\hline \multicolumn{5}{|l|}{ Saturated } \\
\hline Lauric $(C 12: 0)$ & $1.3 \pm 0.09$ & $0.2 \pm 0.01$ & - & - \\
\hline Nonanodioic & $1.4 \pm 0.03$ & $0.2 \pm 0.00$ & - & - \\
\hline Myrstic $(C 14: 0)$ & $8.1 \pm 0.49$ & $1.0 \pm 0.06$ & $0.6 \pm 0.05$ & $0.0 \pm 0.00$ \\
\hline Pentadecanoic (C15:0) & $2.3 \pm 0.05$ & $0.3 \pm 0.01$ & - & - \\
\hline Palmitic $(C 16: 0)$ & $230.6 \pm 2.42$ & $27.6 \pm 0.29$ & $653.3 \pm 44.19$ & $12.7 \pm 0.86$ \\
\hline Margaric $(C 17: 0)$ & $4.2 \pm 0.14$ & $0.5 \pm 0.02$ & $3.8 \pm 0.29$ & $0.1 \pm 0.01$ \\
\hline Stearic $(C 18: 0)$ & $37.0 \pm 0.55$ & $4.4 \pm 0.02$ & $360.6 \pm 9.30$ & $7.0 \pm 0.18$ \\
\hline Arachidonic $(C 20: 0)$ & $2.4 \pm 0.15$ & $0.3 \pm 0.02$ & $26.7 \pm 1.80$ & $0.5 \pm 0.04$ \\
\hline Behenic $(C 22: 0)$ & $7.3 \pm 0.44$ & $0.9 \pm 0.05$ & $6.9 \pm 0.26$ & $0.1 \pm 0.01$ \\
\hline Lignoceric $(C 24: 0)$ & - & - & $2.6 \pm 0.21$ & $0.1 \pm 0.00$ \\
\hline Total & 294.6 & 35.3 & $1,054.5$ & 20.5 \\
\hline \multicolumn{5}{|l|}{ Monounsaturated } \\
\hline 3-Phenyl-2-propenoic & $1.5 \pm 0.11$ & $0.2 \pm 0.01$ & - & - \\
\hline 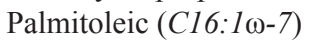 & $4.1 \pm 0.15$ & $0.5 \pm 0.02$ & $4.1 \pm 0.31$ & $0.1 \pm 0.01$ \\
\hline Oleic $(C 18: 1 \omega-9)$ & $146.9 \pm 0.63$ & $17.6 \pm 0.08$ & $1,173.6 \pm 34.04$ & $22.9 \pm 0.66$ \\
\hline cis-Vaccenic $(C 18: 1 \omega-7)$ & $15.9 \pm 1.27$ & $1.9 \pm 0.15$ & $93.5 \pm 4.47$ & $1.8 \pm 0.09$ \\
\hline 11-Eicosenoic & - & - & $15.0 \pm 0.64$ & $0.3 \pm 0.01$ \\
\hline C18:1 $\Delta 9-13 \mathrm{OH}-12-\mathrm{OMe}$ & - & - & $5.0 \pm 0,21$ & $0.1 \pm 0.00$ \\
\hline Total & 168.4 & 20.2 & $1,291.2$ & 25.2 \\
\hline \multicolumn{5}{|l|}{ Polyunsaturated } \\
\hline Linoleic $(C 18: 2 \omega-6)$ & $220.8 \pm 3.95$ & $26.4 \pm 0.47$ & $2,791.8 \pm 104.69$ & $54.3 \pm 2.04$ \\
\hline Linolenic $(C 18: 3 \omega-3)$ & $151.0 \pm 4.29$ & $18.1 \pm 0.51$ & - & - \\
\hline Total & 371.8 & 44.5 & $2,791.8$ & 54.3 \\
\hline Total & 834.8 & 100.00 & $5,137.5$ & 100.00 \\
\hline
\end{tabular}

${ }^{a}$ Values are the mean \pm SD of three measurements.

${ }^{\mathrm{b}}$ Total dry mater.

c $\%$ of total fatty acid.

- Not detected.

(2.6-4.3) (Muller and Tobin, 1986) and similar to that of $Z$. sonorensis fruit (5.4) (Montiel-Herrera et al., 2005).

Vitamin C was undetected in pingüica fruits. Drupes, such as pingüica, are poor sources of vitamin $\mathrm{C}$; peaches (Prunus persica), nectarines (Prunus persica var. nucipersica), prunes (Prunus spp.), and avocado (Persea americana) present contents lower than $10 \mathrm{mg} / 100$ $\mathrm{g}$ of edible portion (USDA, 2009). Vitamin C was not detected in Zizyphus sonorensis fruit (Montiel-Herrera et al., 2005).
The moisture of pingüica fruit was similar to those of other fruit drupes such as peaches $(88.9 \%)$, nectarines (87.6\%), and prunes (87.5\%) (USDA, 2009).

The phenolics content of pingüica (Table 2) was higher than those of tropical fruits such as papaya (Carica papaya) (28 mg/100 g f.w.), bananas (Musa sapientum) (51 $\mathrm{mg} / 100 \mathrm{~g}$ f.w.), or oranges (Citrus sinensis) $(75 \mathrm{mg} / 100 \mathrm{~g}$ f.w.), and it was comparable with that of guava (Psidium guajava) (138-179 mg/100 g f.w.) and star fruit (Averrhoa carambola) (131 mg/100 g f.w.) (Lim et al., 2007). 
Antioxidant activity of pingüica (Table 2), using DPPH, was higher than reported for tropical fruits such as dragon fruit (Hylocereus undatus) (13.5 mg EVC/100 g f.w.) and guava (218 mg EVC/100 g f.w.). On the other hand, with the ABTS method, pingüica antioxidant activity (Table 2) was higher than those of Opuntia fruits (13-33 $\mathrm{mg} \mathrm{EVC/100}$ g f.w.) (Cayupán et al., 2011); and considering the Trolox equivalents values, this fruit must be grouped with fruits such as tomato, watermelon, white grape, and pumpkin that showed antioxidant activities lower than $500 \mu \mathrm{M}$ TE/100 g f.w. (Pennington and Fisher, 2009). Antioxidant activity and phenolics content are considered as important food characteristics for the prevention of chronicdegenerative diseases such as cancer, diabetes, obesity, and heart diseases (Kaur and Kapoor, 2001; Lule and Xia, 2005; Kaliora and Dedoussis, 2007). The consumption of pingüica fruits could provide health benefits by their content of phenolics and antioxidant activity.

The protein content of E. tinifolia pulp (16.5\% d.w.) was higher than for common fruits and vegetables, for example, apple (Malus domestica) has 1.9\% d.w., rhubarb (Rheum rhabarbarum) $14.08 \%$ d.w., and dragon fruit (Hylocereus undatus) 10.26\% d.w. (USDA, 2009; Ledezma-Solano et al., 2010). The content of lipids of E. tinifolia fruit $(0.2 \%$ d.w. $)$, determined by the Soxhlet method, was lower than those of common fruits (USDA, 2009; Ledezma-Solano et al., 2010). E. tinifolia fruits had a high content of ash (12.6\% d.w.), suggesting that they could be an interesting source of minerals; they are high in selenium (12.3 $\mu \mathrm{g} / 100 \mathrm{~g}$ f.w.), good for magnesium $(10 \mathrm{mg} / 100 \mathrm{~g}$ f.w.), but poor in calcium, iron, manganese, and zinc (Table 1) (FNB/FNIC, 2009; Ledezma-Solano et al., 2010); however, their mineral content was higher than those of many common fruits (Bourges et al., 2009; Ledezma-Solano et al., 2010). Selenium deficiencies are rare worldwide except in China, Finland, and New Zealand; nevertheless, selenium consumption is suggested because this mineral is a cofactor of glutathione peroxidase, an important enzyme which complements the chemical antioxidant defenses (for example, vitamins E and C) (Mahan and Escott-Stump, 2001). The crude fiber of E. tinifolia fruits was higher than those of some native fruits of Sinaloa (for example, Vitex mollis and Zizyphus sonorensis) (Montiel-Herrera et al., 2004; MontielHerrera et al., 2005; Pío-León et al., 2009). Contrasting the provided energy $(\mathrm{kJ} / 100 \mathrm{~g}$ portion), the value for $E$. tinifolia fruit (1 $227 \mathrm{~kJ})$ was lower than values for most of the common fruits and similar to lemon (1 $101 \mathrm{~kJ})$ and lime (1 $069 \mathrm{~kJ})$ (USDA, 2009); as well as to coconut (1 011 kJ) (Ledezma-Solano et al., 2010).

The fruits of E. tinifolia had low concentrations of tannins ( $0.4 \mathrm{mg} / 100 \mathrm{~g}$ d.w.) (Table 1$)$; the content of phytic acid was $0.2 \%$ f.w., lower than the registered value for the highly consumed Phaseolus spp. (0.8-1.1\%) and soybean $(1.6 \%)$; thus, it is expected that E. tinfolia consumption does not induce anti-nutritional effects (Oatway et al., 2001; Shamsuddin, 2002), on the contrary it may induce health benefits. It has been reported that diets containing phytates (0.5-1.5\%) improve the lipid profile of serum and liver of old rats and the glucose level of diabetic rats (SungHyen et al., 2006; Sung-Hyen et al., 2007). Phytic acid may have positive effects for the prevention or treatment of cancer (Shamsuddin, 2002).

Commonly, fruits are not a rich source of lipids, but carbohydrates (USDA, 2009; Ledezma-Solano et al., 2010), and the vegetable oils are mainly obtained from seeds with some exceptions such as avocado and olive oil; contrasting with the main fatty acid of E. tinifolia pulp, in these fruits the main component was oleic acid (USDA, 2009). Fatty acids of E. tinifolia pulp were $0.83 \%$ d.w. (Table 3), this value was higher than that obtained by the AOAC technique (Table 1) and it must be due to differences in the extraction methods. Contrasting with the fatty acid composition of cherimoya (Annona cherimola Mill.) mesocarp (Gutiérrez et al., 2005), their main components were the same (i.e. palmitic was highest, followed by linoleic and oleic acid) and the $\mathrm{C} 18$ family represents more than $50 \%$ of total fatty acids, common characteristic of fruits. For the essential fatty acids, the ratio $\omega-6 / \omega-3$ for cherimoya in physiological maturity is 1.56 whereas it was 1.46 for E. tinifolia pulp, a value lower than 2 is considered beneficial for human health.

The fatty acid profile of pingüica seeds was similar to that of Cucurbita spp. seeds and of corn germen with linoleic, oleic, and palmitic acid as the main components, as well as a 4/1 ratio for unsaturated/saturated components (Astiasarán and Martínez, 2000; Applequist et al., 2006). In oils from seeds are commonly found essential fatty acids but with variable ratios (Astiasarán and Martínez, 2000). In pitaya seeds (Hylocereus spp.), $51 \%$ of total fatty acids were essential with $50 \%$ of linoleic, corresponding with the values for E. tinifolia seed. The essential fatty acid content of E. tinifolia seed (54.3\%) was higher than for canola (38\%), similar to sesame (45\%), and lower than in other oil-grains (for example, sunflower 68\%, flaxseed $72 \%$, and safflower $75 \%$ ) (Ariffin et al., 2009).

Physicochemical, nutritional, and antioxidant characteristics of E. tinifolia fruit are being reported here for the first time. This fruit is a high source of ash, selenium, and antioxidant compounds. This research improves the knowledge of plants from Mexico and will promote their appreciation. E. tinifolia fruits could be an interesting source of nutrients if included in diet, and more studies 
must be carried out to design and implement strategies for the rational use of E. tinifolia.

\section{Acknowledgments}

We would like to thank the Consejo Nacional de Ciencia y Tecnología, Consejo Estatal de Ciencia y Tecnología and Universidad Autónoma de Sinaloa (UAS) for financial support; as well as Dr. Rito Vega-Aviña, Agronomy Faculty, UAS, for his help in taxonomic identification of plant material.

\section{Literature cited}

Alcántar-González, G. and M. Sandoval-Villa. 1999. Procedimientos analíticos. In Manual de Análisis Químicos de Tejido Vegetal, G. Alcántar-González and M. SandovalVilla (eds.). Sociedad Mexicana de la Ciencia del Suelo, A.C. México, D F. p. 40-42.

AOAC (Association of Official Analytical Chemists). 1990. Official methods of analysis. Association of Official Analytical Chemists, Inc. Washington, D.C. p. 80, 912, 915, 917, 918.

Applequist, W. L., B. Avula, B. T. Schaneberg, Y. H. Wang and I. A. Khan. 2006. Comparative fatty acid content of seeds of four Cucurbita species grown in a common (shared) garden. Journal of Food Composition and Analysis 19: 606-611.

Argueta, C. Z. A. and S. Mata. 2009a. Atlas de las plantas de la medicina tradicional mexicana. Ehretia tinifolia L. Universidad Nacional Autonoma de Mexico, D. F., México. http://www.medicinatradicionalmexicana.unam.mx/ monografia.php?1=3\&t=Ehretia\%20tinifolia\&id=7291.; last access: 28.VI.2010.

Argueta, C. Z. A. and S. Mata. 2009b. Flora medicinal indígena de méxico. Flora medicinal mayo de la región de el Fuerte y Choix, Sinaloa. Pingüica. Universidad Nacional Autónoma de México, D. F., México. http://www.medicinatradicionalmexicana.unam.mx/ flora2.php $? 1=4 \&$ po $=$ mayo $\&$ te $=$ Ehretia_tinifolia DC.\&id=5444\&clave_region=11; last acces: 20.IX.2010.

Ariffin, A. A., J. Bakar, C. P. Tan, R. A. Rahman, K. R. and C. C. Loi. 2009. Essential fatty acids of pitaya (dragon fruit) seed oil. Food Chemistry 114:561-564.

Astiasarán, I. and J. F. Martínez. 2000. Alimentos: composición y propiedades. McGraw-Hill interamericana. Madrid, España. p. 115-120.

Benítez-Badillo, G., M. T. P. Pulido-Salas and M. EquihuaSamora. 2004. Árboles multiusos nativos de Veracruz para reforestación, restauración y plantaciones. Instituto de Ecología, A.C., Sigolfo, Conafor. Xalapa, Veracruz, México. $108 \mathrm{p}$.

Bourges, H., E. Casanueva and J. L. Rosado. 2009.
Recomendaciones de ingestión de nutrimentos para la población mexicana. Bases fisiológicas. Tomos 1 y 2 . Editorial Médica Panamericana D. F., México. p. 188-193, 372-373.

Capistran-Barradas, A., P. Moreno-Casasola and O. Defeo. 2006. Postdispersal fruit and seed removal by the crab Gecarcinus lateralis in a coastal forest in Veracruz, Mexico. Biotropica 38:203-209.

Cayupán, Y. S. C., M. J. Ochoa and M. A. Nazareno. 2011. Health-promoting substances and antioxidant properties of Opuntia sp. fruits. Changes in bioactive-compound contents during ripening process. Food Chemistry 126:514-519.

Cordain, L. 1999. Cereal grains: humanity's double-edged sword. World Review of Nutrition and Dietetics 84:19-73.

Delgado-Vargas, F. and O. Paredes-López. 2002. Natural Colorants for Food \& Nutraceutical Uses. CRC Press. Boca Raton. p. 266-267.

FDA (Food and Drug Administration). 2009. US government laws, regulations, decisions, and guidelines catalog. code of federal regulations, title 21. http://www.accessdata.fda. gov/scripts/cdrh/cfdocs/cfcfr/CFRSearch.cfm; last access: 28.I.2010.

FNB/FNIC (Food and Nutrition Board, Food/Nutrition Information Center). 2009. Dietary reference intakes. http://fnic.nal.usda.gov/nal_display/index.php?info_ center $=4 \&$ tax_level $=3 \&$ tax_subject $=256 \&$ topic_ id=1342\&level3_id=5140; last access: 28.VII.2010.

Gottschling, M. and H. H. Hilger. 2004. Characterisation of a novel fruit type found in Ehretia (Ehretiaceae, Boraginales). Blumea 49:145-153.

Gutiérrez, M., M. M. Sola and A. M. Vargas. 2005. Fatty acid composition of phospholipids in mesocarp of cherimoya fruit during ripening. Food Chemistry 90:341-346.

Kaliora, A. C. and G. V. Dedoussis. 2007. Natural antioxidant compounds in risk factors for CVD. Pharmacological Research 56:99-109.

Kaur, C. and H. Kapoor. 2001. Antioxidants in fruits and vegetables - the millennium's health. International Journal of Food Science and Technology 36:703-725.

Lara-López, M. S. and A. González-Romero. 2002. Alimentación de la iguana verde Iguana iguana (squamata: iguanidae) en La Mancha, Veracruz, México. Acta Zoológica Mexicana 85:139-152.

Latta, M. and M. Eskin. 1980. A simple and rapid colorimetric method for phytate determination. Journal of Agricultural and Food Chemistry 28:1313-1315.

Ledezma-Solano, J. A., A. Chávez-Villasana, F. Pérez-GilRomo, E. Mendoza-Martínez and C. Calvo-Carrillo. 2010. Composición de alimentos Miriam Muñoz de Chávez. Valor nutritivo de los alimentos de mayor consumo. McGraw-Hill. México, D. F. p. 83-97.

Lim, Y. Y., T. T. Lim and J. J. Tee. 2007. Antioxidant properties of 
several tropical fruits: A comparative study. Food Chemistry 103:1003-1008

Lule, S. and W. Xia. 2005. Food Phenolics, Pros and Cons: A Review. Food Reviews International 21:367-388.

Mahan, L. K. and S. Escott-Stump. 2001. Nutrición y dietoterapia, de Krause. McGraw-Hill Interamericana. México, D F. p. 154-156.

Martínez-Valverde, I., M. J. Periago and G. Ros. 2000. Significado nutricional de los compuestos fenólicos en la dieta. Archivos Latinoamericanos de Nutrición 50:5-18.

Martínez, M. 1979. Catálogo de nombres vulgares y científicos de plantas mexicanas. Fondo de Cultura Económica. México, D F. p. 93-1071.

Merrill, A. L. and B. K. Watt. 1973. Energy values of foods... basis and derivation. Agricultural handbook no 74. US Government Printing Office. Washington, D.C. p. 24-51.

Miller, J. S. 1989. A revision of the new world species of Ehrethia (Boraginaceae). Annals of the Missouri Botanical Garden 76:1050-1076.

Monrroy-Ortíz, C. and R. Monrroy. 2006. Las plantas, compañeras de siempre. La experiencia en Morelos. UAEM, Conabio, CIB-UAEM, Conanp. Cuernavaca, Morelos, México. p. 201.

Montiel-Herrera, M., I. L. Camacho-Hernández, A. Ríos-Morgan and F. Delgado-Vargas. 2004. Partial physicochemical and nutritional characterization of the fruit of Vitex mollis (Verbenaceae). Journal of Food Composition and Analysis 17:205-215.

Montiel-Herrera, M., S. Campista-León, I. L. CamachoHernández, A. Ríos-Morgan and F. Delgado-Vargas. 2005. Physicochemical and nutritional characteristics of the fruit of Zizyphus sonorensis S. Wats (Rhamnaceae). International Journal of Food Science and Nutrition 56:587-596.

Muller, H. G. and G. Tobin. 1986. Nutrición y ciencia de los alimentos. Acribia. Zaragoza. España. p. 167-170.

Oatway, L., T. Vasanthan and J. H. Helm. 2001. Phytic acid. Food Reviews International 17:419-431.

Park, P. W. and R. E. Goins. 1994. In situ preparation of fatty acid methyl esters for analysis of fatty acid composition in foods.
Journal of the American Oil Chemist's Society 59:1262-1266.

Pennington, J. A. T. and R. A. Fisher. 2009. Classification of fruits and vegetables. Journal of Food Composition and Analysis 22S:S23-S31.

Pío-León, J. F., G. López-Angulo, O. Paredes-López, M. J. UribeBeltrán, S. P. Díaz-Camacho and F. Delgado-Vargas. 2009. Physicochemical, nutritional and antibacterial characteristics of the fruit of Bromelia pinguin L. Plant Foods for Human Nutrition 64:181-187.

Price, M. L., S. van Scoyoc and L. G. Butler. 1978. A critical evaluation of the vanillin reaction as an assay for tannin in sorghum grain. Journal of Agricultural and Food Chemistry 26:1214-1218.

Rubinson, J. F. and J. Neyer-Hilvert. 1997. Integration of GC/MS instrumentation into the undergraduate laboratory: separation and identification of fatty acids in commercial fats and oils. Journal of Chemical Education 74:1106-1107.

Shamsuddin, A. M. 2002. Anti-cancer function of phytic acid. Journal of Food Science and Technology 37:769-782.

Sung-Hyen, L., P. Hong-Ju, C. Hye-Kyung, C. So-Young, J. Hyun-Jin, C. Soo-Muk, K. Dae-Yong, K. Min-Soo and S. L. Hyun. 2007. Dietary phytic acid improves serum and hepatic lipid levels in aged ICR mice fed a high-cholesterol diet. Nutrition Research 27:505-510.

Sung-Hyen, L., P. Hong-Ju, C. Hye-Kyung, C. So-Young, C. SooMuk and S. L. Hyun. 2006. Dietary phytic acid lowers the blood glucose level in diabetic KK mice. Nutrition Research 26:474-479.

USDA (Department of Agriculture, Agricultural Research Service). 2009. Nutrient Database for Standard Reference, Release 22. http://www.ars.usda.gov/ba/bhnrc/ndl; last access: 4.X.2009

Wrolstad, R. E. (ed). 2001. Current Protocols in Food Analytical Chemistry. John Wiley and Sons Inc.

Zapata, S. and J. P. Dufour. 1992. Ascorbic, dehydroascorbic and isoascorbic acid simultaneous determinations by reverse phase ion interaction HPLC. Journal of Food Science 57:506-511. 